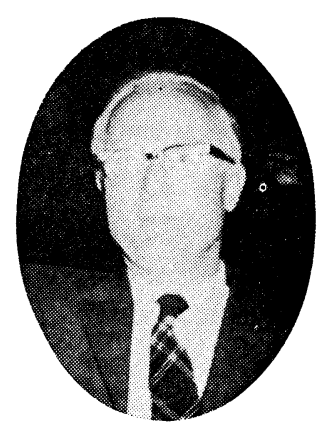

Why make predictions? World transport needs Bulk carriers

Finished-product carriers Shipbuilding

Ship operations

\title{
Merchant Ships in the Year 2000
}

\author{
Harry Benford*
}

(Prepared for the Special Lecture Meeting Organized by the Society of Naval Architects of Japan on May 21, 1971, Tokyo, Japan)

\section{CONTENTS}

(3) Radical configurations

(4) Air freight competition

(5) Maritime technological progress

(5) The twin prerequisites to progress (12)
Bibliography

\section{ABSTRACT}

This paper stresses the rapidity of change in today's world and underscores the necessity of learning to live with change. It points to probable future growth in the worldwide need for ocean transport and predicts the relative importance of various kinds of ships in meeting those needs. Trends in ship production techniques receive attention, as does the probable future demand for air cushion vehicles, hydrofoil craft, and other novel types of marine vehicle. The problem of air freight competition is discussed briefly. The place for education and research in a changing world receives particular emphasis.

\section{Why Make Predictions?}

No one can pretend to know the future, or even to speak of it in a completely unbiased manner. Nevertheless, as several observers have ${ }^{(1-3) \dagger}$ pointed out, these are rapidly changing times. The engineer, businessman, or government official who fails to plan for change will inevitably make bad decisions. I do not mean to imply that recognizing the inevitability of change will automatically lead to good decisions. There are still great risks in any venture, but the most successful decision maker will be the one who most often correctly guesses what the changes will be.

There are three intricately related categories of change that affect the future of merchant ships : changing commercial needs, changing political influences, and changing technological capabilities. This paper is concerned almost exclusively with the last category: technological capabilities. We shall look at the ships themselves, their general configurations, how they are operated, and how they are put together. We shall also look at some of the related, contributing technologies such as materials of construction and analytical techniques. We shall examine the potential role of air cushion vehicles, hydrofoil craft, cargo submarines, catamarans, and other advanced marine vehicles, as well as airfreight competition.

Let me close this introductory section on what may sound like a parochial and selfish note. Engineers, above all, should favor and promote technological progress. Without progress, there would be no need for engineers. Industry and government could do very well without us. We, as a profession, are needed only under changing conditions. Indeed, the Society of Naval Architects of

* Professor, Department of Naval Architecture and Marine Engineering, College of Engineering, The University of Michigan, U.S.A.

† Numbers in parentheses refer to Bibliography. 
Japan, like all other technical societies, exists primarily to foster technological change and thus promote the welfare of its members along with the welfare of society. The spectacular rise of the Japanese maritime industry since World War II offers ample testimony to the thesis that technological advancement brings prosperity to the industry, to the individual, and to the nation. I can only presume that the Society of Naval Architects of Japan deserves much credit for the peerless position that Japan now holds as a world maritime power.

\section{World Transport Needs}

Wise engineers, before they undertake a design, try to understand the useful purpose of that which they intend to produce. In our case, then, we want to understand at least a little about world shipping needs.

A prominent shipowner has been quoted as saying that God must be a shipowner; He put none of his raw materials where they were needed. Since two-thirds of the globe is covered with water, it follows that overseas transport is necessary to our civilization. It is true that some misguided individuals have implied that God may be in the airfreight business, rather than the marine transport business. That is a heresy that we shall put down in a later section.

If we look at a world map we find that Japan, the United States, and Western Europe are the world's leading centers of industrial production. These three centers contribute the preponderance of the manufactured goods that move in world trade today. Useful raw materials and farm products, on the contrary, are found in widely scattered locations around the globe. Adam Smith's classical economic theory proposes that world trade consists of raw materials moving from underdeveloped nations to industrial nations in exchange for finished products moving in the other direction. That kind of trade does indeed exist and does indeed promote the economic welfare of all parties concerned. Strangely enough, however, the most important ocean commerce in terms of value of goods moved (and freight paid) is that between the great industrial nations. This is most evident in the lucrative North-Atlantic trades, but the trade between Japan and the West Coast of the United States is of great vitality, too.

Perhaps the most important thing that can be said about world trade is that it is growing. Various experts $^{4,5)}$ predict that this growth will continue at an accelerating pace. A typical forecast is that there will be a five-fold increase in world trade during the final third of this century. This sort

\section{PROJECTED WORLD OCEAN-BORNE TRADE}

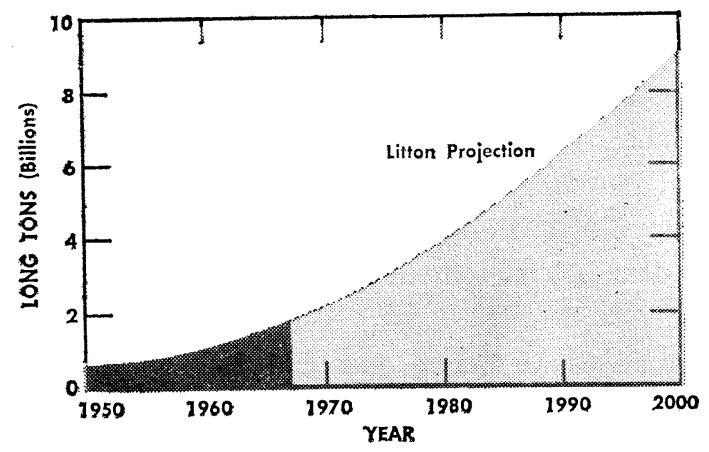

Eig. 1 Independent studies of world shipping trends confirm that the demand for overseas transport is accelerating. A recent Litton study is typical in predicting a five-fold increase during the final third of this century. of growth leads to economies of scale in transportation (e. g. ever larger ships) and to economies of specialization (e. g. automobile carriers). Technical advancements allowed by growth lead to lowered cost of transport, which in itself contributes to growth in trade.

Assuming the truth of the assertion that ocean commerce will continue to expand, how will the maritime industry respond to that demand? There will, I believe, be two primary channels of development. Bulk carriers (by which term I include tankers) will follow one channel, finished product carriers (mostly cargo liners) will follow another. We shall deal with these parallel developments in the next two sections. 


\section{Bulk Carriers}

Bulk cargoes are usually found in enormous supply; which means that bulk cargo ships can take full advantage of the economies of scale. A ten-fold increase in deadweight typically requires roughly a three-fold increase in horsepower (for the same speed). Crew complements increase but slowly with ship size - and so forth. As a consequence, unit costs of transport vary approximately with the deadweight raised to the twothirds power. For example, on a given trade route, a 10,000 DWT tanker might have a required rate of 700 yen per ton, whereas a 100, 000 DWT tanker would require only 150 yen per ton ${ }^{6}$. Telling all this to you, a Japanese audience, may seem ridiculous, but there is always the possibility that you have been so busy doing things right that you have never found time to analyze the reasons for your success.

What limits the size of bulk carriers? Initially the physical constraints of harbor depths or lock dimensions are felt. Those limitations can often

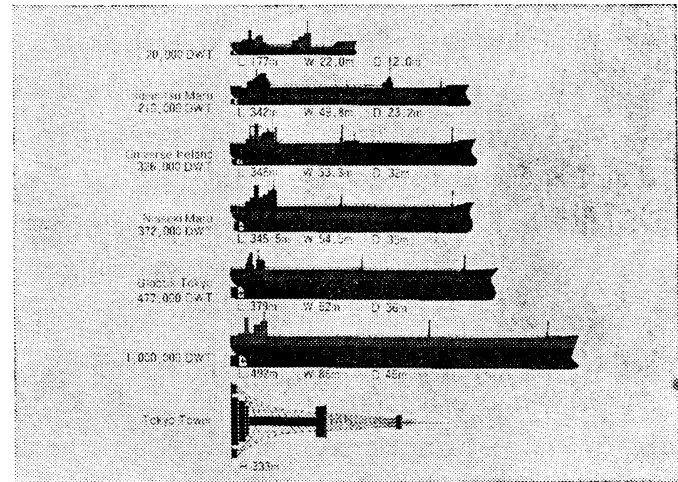

Fig. 2 Bulk carriers find their cargo in unlimited supply and can therefore take advantage of the economics of scale. By the year 2000, the million-ton DWT tanker will probably be reality. be escaped via offshore loading and unloading terminals. The advent of Marcona Corporation's slurry iron-ore carrier suggests the possibility of offshore terminals in the dry bulk trades, as well. Ultimately, bulk carrier size will be limited primarily by the demands of the transport system in which the ship serves. Let me explain. We could build tankers of such enormous capacity that the quantitative needs of the principal petroleum terminals could be satisfied with a single delivery per year (or even one per decade). Obviously, such a transport system would be uneconomical because the necessary receiving tanks would be so outrageously expensive. (This is another example of how modern ship design must be integrated into the complete transport system.) Other, perhaps less critical constraints will be found in ocean depth limits in such key passages as the Malacca Strait. Another constraint will be in the number of dry docks and construction facilities likely to be available for a severely limited number of extremely large ships.

In the matter of speed, we are unlikely to see any spectacular changes in the case of bulk carriers. Sixteen knots is almost a universal optimum. The exception is where hull costs are exceptionally high, as in LNG carriers ${ }^{7}$.

In oil tanker development, we may expect to see important developments, some perhaps radical, arising from public pressures against further contamination from oil spills. As a start, maneuverability must be greatly improved, and collisions and groundings must become things of the past. I do not suggest how these wonders are to be accompliehed; but I am confident that there are economically sound technological solutions to the growing menace of oil pollution.

\section{Finished-Product Carriers}

General cargo liners and other finished-product carriers are inevitably limited in economic size by the availability of cargo. Thus we should not expect the rapid trend toward large deadweights that we are experiencing in bulk carriers. Twenty years ago, a cargo capacity of 10,000 tons was considered large. Today, Sea-Land is buying ships of twice that capacity and those ships will be the biggest of their kind. So, in a period of two decades, while tanker size has increased over 
twenty-fold, cargo liner size has merely doubled. Moreover, if my guess is correct, the Sea-Land ships will remain the largest of their kind for a long time.

The question of speed is difficult to analyze. Twenty years ago, the 20-knot Mariners were the fastest cargo liners afloat. The new Sea-Land Ships with their 33-knots indicate the growth in speed since the advent of the Mariners. Again, I should guess that the Sea-Land ships may well establish a plateau in speed that will remain unchallenged for many years. This is a shaky prediction, however, because the selection of sea speed is more a matter of sales appeal than of engineering. It involves guessing about how mach emphasis future customers will put on high speed and, more importantly, it involves guessing what strategies your competitors may adopt.

The present conference system, which ignores speed in setting freight rates, has been an important factor in the trend toward higher speeds. I predict - and this may be wishful thinking - that the conferences will change their ways and so cool the current over-emphasis on speed. Unless they do so, competition between shipowners will surely push speeds to such uneconomic levels that the airfreight industry will be the only winner.

Obviously, one big change ahead will be in the completion of the revolution in cargo handling. The majority of commerce in manufactured goods will be in unitized form : pallets, containers, preloaded barges, or various combinations thereof. Differing economic circumstances will encourage differing solutions, and there is little reason to believe that any one form of unitization will crowd out the others.

The ease of getting cargo on and off these modern ships will lead to new concepts of operation. Transshipping will become fairly common. High speed container ships will shuttle between major

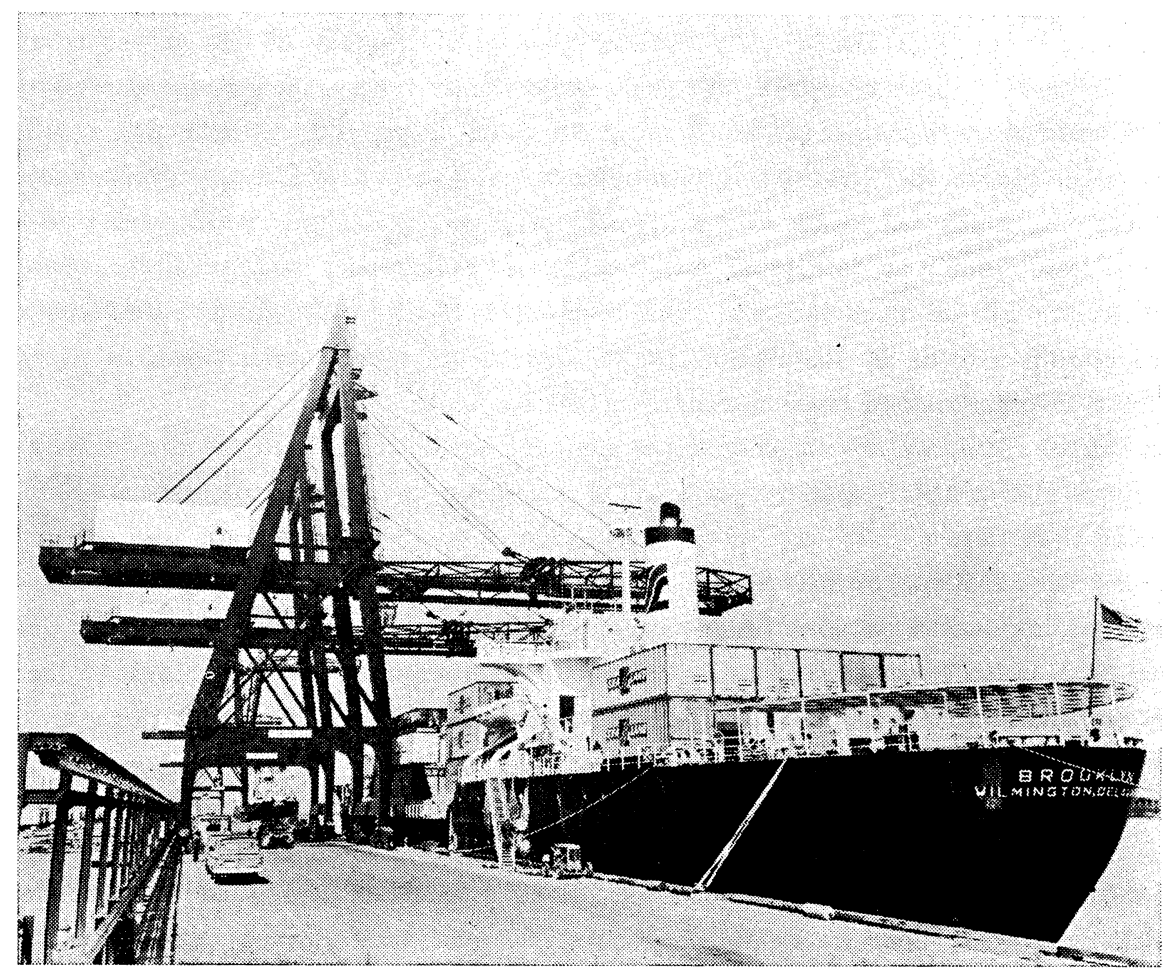

Fig. 3 General cargo carriers are undergoing revolutionary changes in cargo handling methods. Ease of loading and unloading cargo will lead to new concepts in fleet operations. 
ports — perhaps only one at each end of a given trade route. Smaller ships, often with their own deck cranes, will handle the consolidation and distribution of cargo to secondary ports. Similarly, transshipping ports (e. g. Hawaii) will allow important gains in transport efficiency.

Break-bulk cargo ships will have a role in serving many minor trade routes and in handling the minority of cargo that defies unitization. They will also be found in the ever-changing tramping trades.

\section{Shipbuilding}

We can expect shipbuilding technology to continue to advance along many separate, yet interconnected paths. New hull materials, new fabricating methods, and new joining techniques will all influence the proud art of ship production. Higher strength steels will come to the fore, possibly followed by aluminum alloys and, eventually, composite materials such as plastics reinforced with high-strength whiskered materials. In steel ships, we may expect to see welding displaced by adhesive bonding. The majority of work in shipyards will be done out of the weather in comfortable, well-lighted buildings. Unless this is done, skilled shipyard workers will be in chronically short supply.

The most important shipyard developments will be in the realm of engineering, planning, and management. Modern numerical control methods will allow mass-production techniques to be applied to non-standard ships. The design and production functions will be carefully integrated and computers will be in widespread use for conceptual design, cost estimating, production planning, weight calculations, detail design, numerical programming, purchasing, billing, and on and on. Computers will free naval architects and production planners from past drudgeries, allowing them to do a maximum amount of creative thinking. The ultimate rewards in innovative shipbuilding methods are difficult to perceive. We can only be sure that they will exist, and the most successful shipyards will be those where innovative minds are most encouraged.

\section{Ship Operations}

As in shipbuilding, the most important developments in ship operations will be in the area of management. This will be a quiet revolution, but managerial decisions will increasingly be based on analytical, often computer-assisted, techniques. The old reliance on intuitive judgment will never be entirely displaced, but the move will be in that direction.

The increasingly knotty problem of finding qualified seagoing personnel will be attacked in different ways. On the one extreme, some ships may be manned by one or more families (as has been done in coastal and river craft for centuries). At the other extreme, some ships will be entirely automated, operating unmanned between pilot stations.

Ships, at least while in the busier harbors and approaches, will be as carefully controlled from shore as are aircraft today. Navigation lights will be several orders of magnitude brighter and turn signal indicators and ship-to-ship telephones will be universal.

Protective coatings will eliminate the age-old battle with corrosion; barnacles will be permanently abolished; rolling and pitching will be eliminated and_-perhaps_—so too will fog.

Navigation satellites and electronic devices will keep continuous track of each ship's location and automaic corrective action will be taken if the ship strays from its prescribed course. Maneuverability and braking capabilities will be radically improved, as will anchoring and mooring systems. (Mooring winches, or their equivalent, will be on the shore rather than on the ships.) Canal locks will be mechanized, allowing faster, safer, damage-free locking operations. Ice operation will become increasingly commonplace. Most ships will rely on icebreaker assistance, but others will be designed 
to operate as independent units. This general area is one that is wide open to new ideas and new techniques. The future is hard to predict.

\section{Radical Configurations}

The natural human craving for ever-higher speed affects every mode of transport, including merchant ships. The displacement type hull, if pushed past present speeds (generally $20 \sim 30$ knots) rapidly loses its natural attributes of efficient transport. Thoughts of turning to hydroplanes are immediately discouraged when one observes the antics of a planing craft in waves. This leads to the hydrofoil craft, which can be seaworthy enough but is limited in size. Hydrofoil craft also run

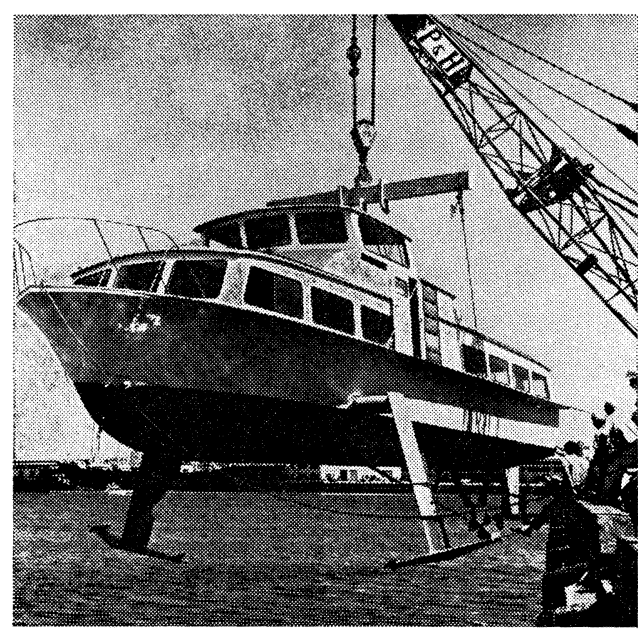

Fig. 4 Hydrofoil craft, being limitted both in size and in efficiency, offer little challenge to conventional cargo ships. Their application will be confined largely to ferry service. By the year 2000, speed of 100 knots may be attained.

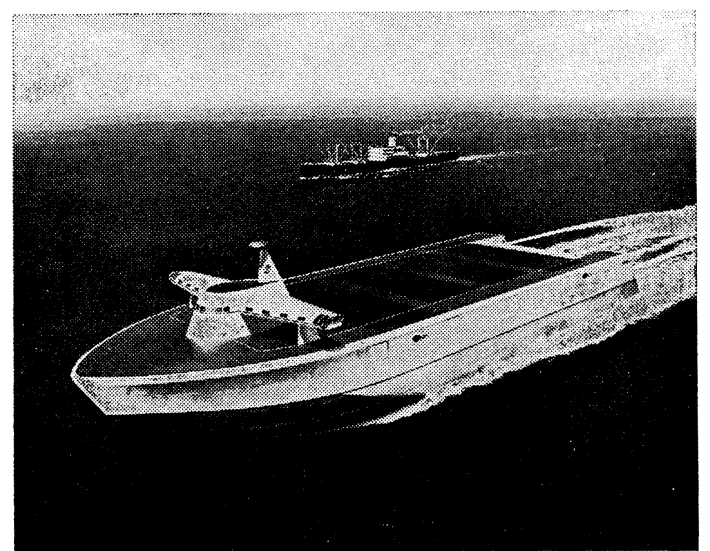

Fig. 5 Air cushion vehicles can be built in large sizes, but are fundamentally inefficient cargo carriers. Their realm of practicality will be in short ferry service and military application. into practical material problems when pushed beyond 40 50 knots, although 100 knots may well be practical by the year 2000 . The next alternative would appear to be the air cushion vehicle. There are no technical limits on the size of such craft, and their speeds could conceivably be as high as 200 knots by the end of the century. Their fatal flaw, however, is their limited weight-lifting capacity. Even the captured-air-bubble variant would apparently be unable to lift enough fuel to make an ocean crossing - at least within the next decade. Experts foresee unit costs of transport in air cushion vehicles at least equal to those of air freight. In most ocean trades, then, hydrofoil craft and air cushion vehicles offer little threat to ships or aircraft. The development of a lightweight nuclear propulsion plant might, of course, change this forecast. Meanwhile, ACVs and hydrofoil craft will find their useful niche in short ferry service, sight-seeing boats, crew-transport boats for offshore stations, etc.

Submarines can escape storms and ice. What they cannot escape is the extra frictional resistance of a submerged upper deck, and many practical and human problems inherent in submerged operation. Submarines may find limited application but are unlikely to revolutionize ocean commerce.

Semi-submerged hulls (e. g. Litton's Trisec) and catamarans both involve complex, expensive structures. They require as-yet nonexistent building and drydocking facilities. Like submarines, there may well be a place for them, but that place will probably not be extensive.

All of the foregoing proposals, except perhaps the submarine, are products of the urge for 


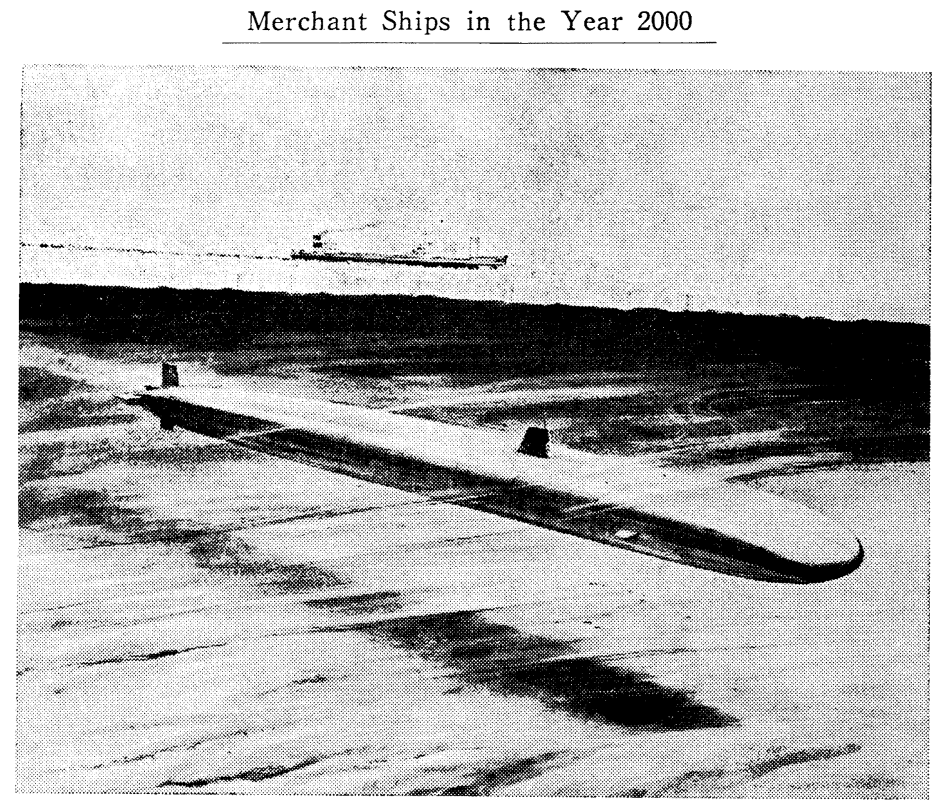

(9)

Fig. 6 Cargo submarines may find limited application in polar regions. They are unlikely to replace surface ship elswhere.

speed. Probably the best overall conclusion we can reach is that the interface between air and water is by nature's intent a poor place for high speed ${ }^{8)}$.

Compoundable or hinged ships offer interesting advantages and equally interesting, but unfortunate, disadvantages. Oceangoing pushed barges, whether single units or flotillas, are a more promising

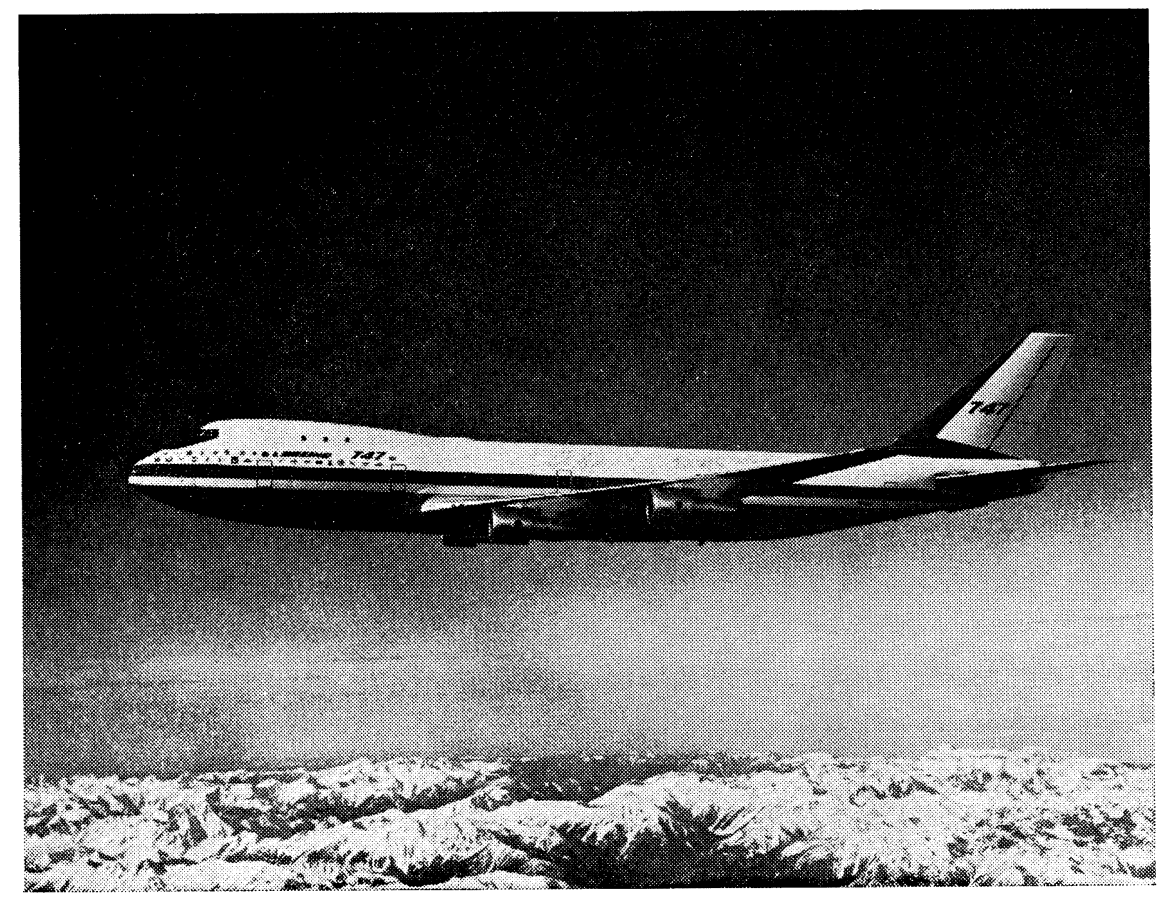

Fig. 7 Some experts predict that air freighters will drive ships from the seas by the end of this century. Economic studies fail to bear them out, however. 
way of achieving the same versatility. Many flexible linkage systems are under consideration and some will surely prove practical. Or, perhaps, the best solution will be to lift the loaded barges on board a big, seagoing ship. But then we are back to what is now considered almost conventional practice, and the LASH and Seabee ships no longer belong in this section on radical configurations.

\section{Air Freight Competition}

A few experte ${ }^{1)}$ have boldly predicted that air freighters will drive merchant ships from the seas by the year 2000. I venture to predict that they are totally wrong. Moreover, I have every intention of waiting until then to proclaim my superiority as a seer. The natural transport efficiency of the displacement hull is simply unbeatable — as long as we keep our high-speed instincts under control. Large bulk carriers have lift-drag ratios of well over 700 , contrasted to perhaps 20 in an aircraft. Unit transport costs in a large tanker are only about one-tenth of a cent per ton-mile, against perhaps 20 cents per ton-mile in an aircraft. As a result, in U.S. overseas trade, to cite an example, ships carry $99.9 \%$ of the cargo by weight. It is true that aircraft are attracting an increasing share of the highest value cargo. They are, again citing U.S. figures for example, capturing about $15 \%$ of the U.S. overseas freight revenues. I predict, however, that the encroachment

LIFT-DRAG RATIO vS CALM-WEATHER SPEED

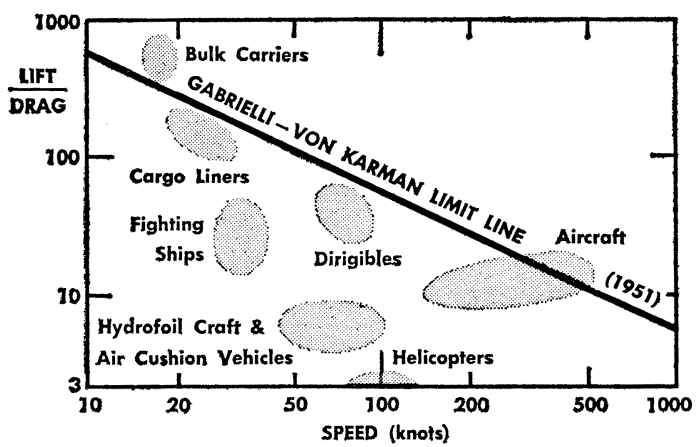

Fig. 8 Nature seemingly dictates that highspeed vehicles will inevitably have low lift-drag ratios. The relatively poor position of hydrofoil craft and air cushion vehicles is evident.

\section{REPRESENTATIVE FREIGHT RATES PER IONG TON-NAUTICAL MILE (Including. Cargo Handling)}

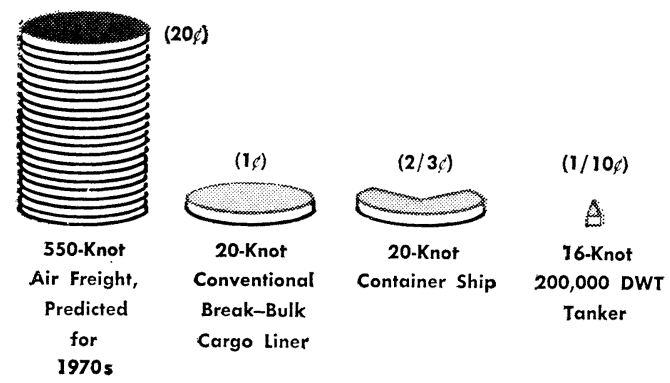

Fig. 9 Unit costs of transportation show a range of 200 to one between air freighters and tankers. will level out to perhaps $0.5 \%$ by weight and $25 \%$ by revenue by the year 2000 .

We are in an era, I believe, where ships are improving faster than aircraft. While the maritime industry of the world is enjoying a technological renaissance, the air industry has divered its best brains and research dollars to the space program, the super-sonic transport, and other essentially uneconomic pursuits. Even if I am wrong in this, let us not forget that any inroads made by air freighters will be more than offset by the absolute growth in total overseas transport needs. We can feel confident in the continuing and, indeed, expanding role of the merchant ship in tomorrow's world.

\section{Maritime Technological Progress}

As already implied, in the world of ocean transport, the displacement ship is here to stay. The truly significant areas of progress lie not so much in eye-catching radical configurations as in evolutionary improvements in conventional ships. We have already mentioned new shipbuilding materials, and new concepts in fleet operations. We may confidently expect similar progress in several other technological categories such as propulsion machinery and navigation systems. As always, much of our progress will flow from the several technologies 


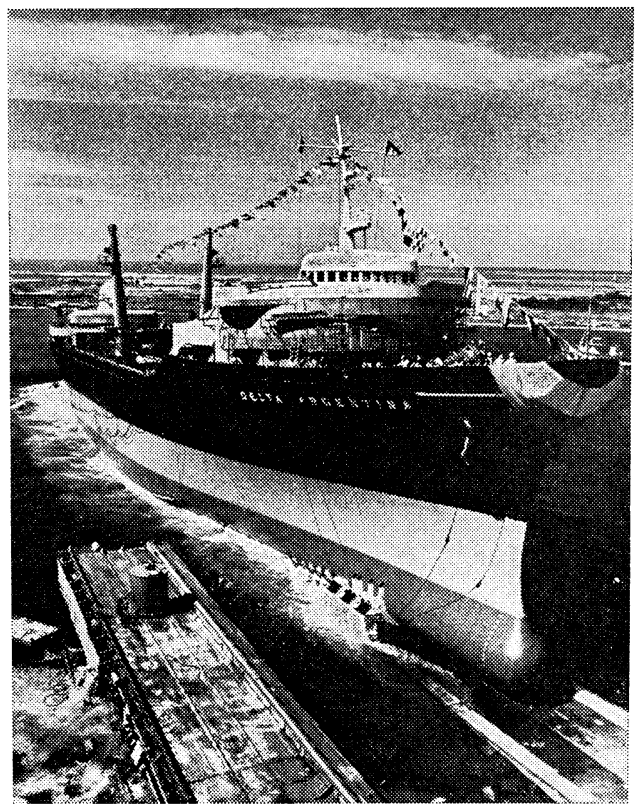

Fig. 10 In the world of ocean commerce, the displacement type ship is here to stay.

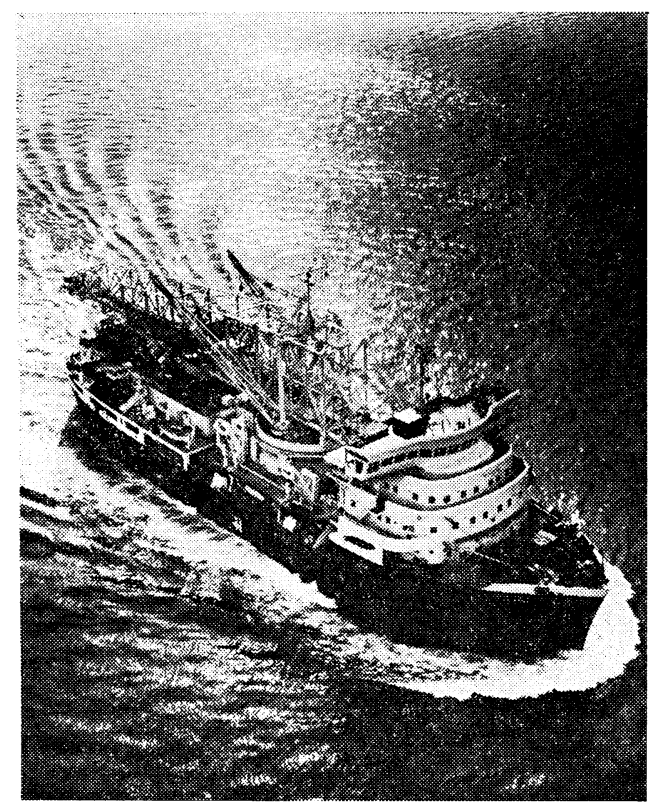

Fig. 11 New dredging systems are econom!cally important.

that relate to the marine industry. Part of our task, then, is to keep abreast of developments in many fields — and to welcome ideas from innovative thinkers in those fields, as well.

We shall see continuing improvements in all manner of analytical techniques. Ship structural loading will be better understood, allowing important reductions in scantlings, in weights, and in costs. Vibrations will be eliminated. Hydrodynamicists will come to understand the physical action of hull wave generation, leading to continuing improvements in hull form and a lessening reliance on empirical model basin research. Systems analysts will improve their trade. Among other advances, they will develop new cost estimating methods necessary to rational decision making in ship design.

In the area of propulsion machinery, steam turbines and diesels will continue their vigorous competition. Gas turbines and, eventually, nuclear plants will also find application. We may, perhaps, experiment with a return to sail propulsion ${ }^{9}$. Modern aerodynamic theory, new lightweight materials, mechanical reefing systems, and weather routing all indicate the possible economic potential of a modern wind-driven bulk-cargo ship. The thought is not at all reactionary and deserves consideration.

New dredging systems will probably come into being. This will encourage further growth in ship size and in the provision of new harbors and canals.

New and improved pliant plastic materials may lead to a revival of interest in the dracone (oil-filled bladder). Plastic bladders may be used, also, as a means of separating oil and water in deep tanks.

Certainly, we cannot possibly foresee all the developments that will take place. What we can foresee, however, is accelerating change. One result will be that optimal ship life will continually decrease, leading to increased shipyard prosperity. It also follows that brain-power and innovative management will become increasingly necessary to survival in this highly competitive world. That leads us then to the final section, which follows. 


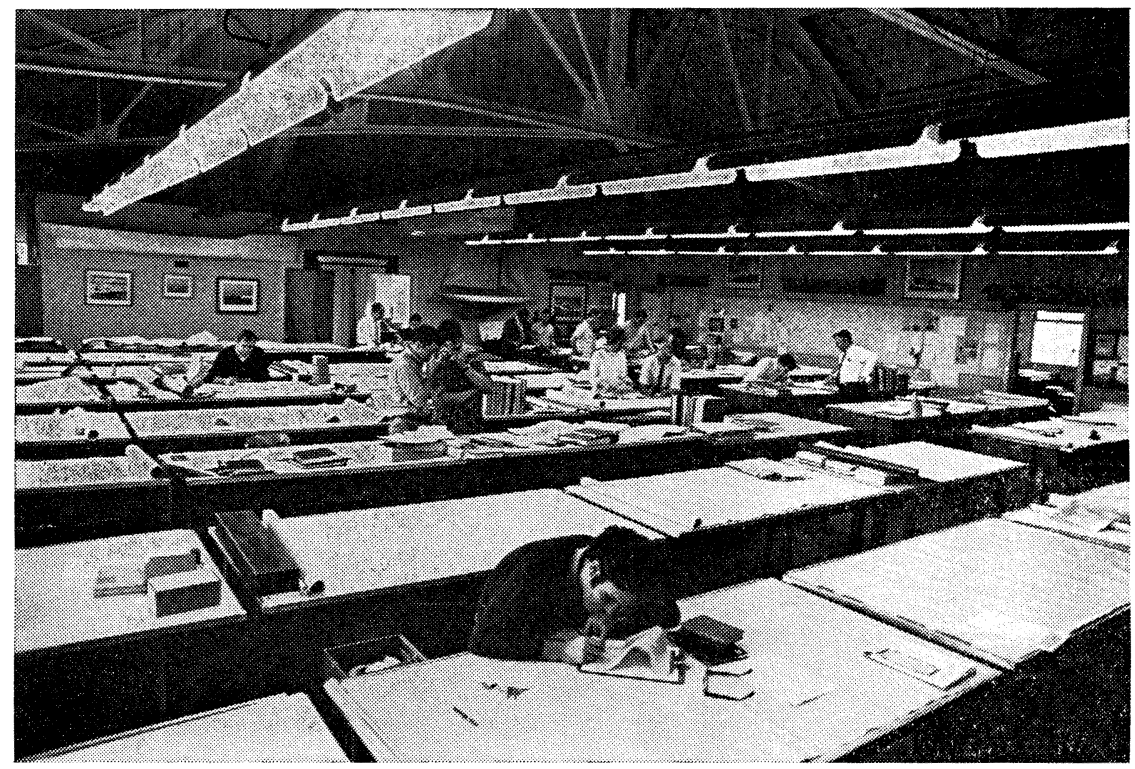

Fig. 12 The key to productivity is educated personnal. An industry must attract capable young people if it is to prosper.

\section{The Twin Prerequisites to Progress}

J. J. Servan-Schreiber in his book The American Challenge ${ }^{10)}$ reveals the secret of America's industrial strength in these words:

Behind the success story of American industry lies the talent for accepting and mastering change. Technological advance depends on virtuosity in management. Both are rooted in the dynamic vigor of American education. There is no miracle at work here. America is now reaping a staggering profit from the most profitable investment of all-the education of its citizens.

Peter Drucker ${ }^{1)}$ puts it this way:

......knowledge has already become the central cost of the American economy. The productivity of knowledge has already become the key to productivity, competitive strength, and economic achievement.

But the statistics, impressive though they are, do not reveal the important thing. What matters is that knowledge has become the central "factor of production" in an advanced, developed economy.

Observers of the international marine industry, such as F. H. Todd ${ }^{11}$, point out that education has indeed played a role in maritime competitive success. The leadership in marine-related education has not come from the United States, however. It has come from such maritime nation as Japan and Norway. The success of the Japanese shipbuilding and Norwegian ship operating industries is a tribute to their understanding of the catalytic effect of education.

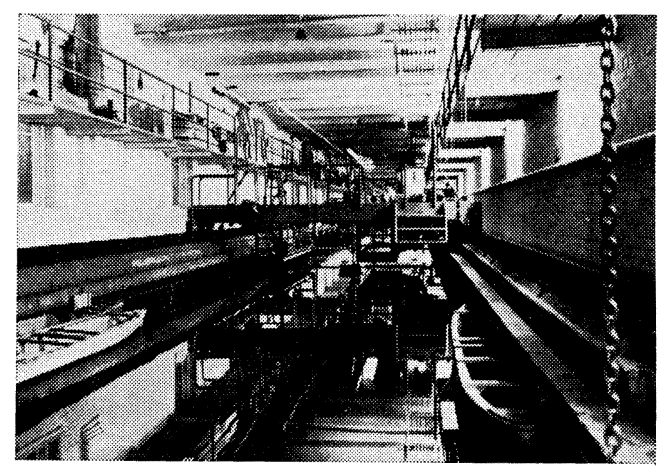

Fig. 13 Another prerequisite to progress is research and development. Model basin work is one important element of maritime research. 
Another ingredient of technological progress is, of course, research and development. The more progressive industries in the United States put at least two percent of their annual budget into $R \&$ $\mathrm{D}$; many of them put considerably more. The importance of $\mathrm{R} \& \mathrm{D}$ in maintaining a competitive position is so obvious as to seem hardly worth mentioning. Yet the fact remains that many maritime nations, many shipowners, and many shipyards spend little or nothing on $\mathrm{R} \& \mathrm{D}$. They are on the road to disaster.

In the changing decades ahead, the nations and the private organizations that survive in the maritime business world will be the ones that encourage innovation, education, and research and development. The successful business managers will not only learn to live with change, they will actively induce it. And they can only induce it if they are backed by a large, competent team of well-educated, innovative engineers and young managers—-what Galbraith ${ }^{12}$ calls the technostructure.

In short, educate and innovate, or step aside in favor of those who will.

\section{Bibliography}

1) Peter F. Drucker, "The Age of Discontinuity", Harper and Row, 1969.

2) Alvin Toffler, "Future Shock", Random House, 1970.

3) Herman Kahn and Anthony J. Wiener, "The Year 2000", MacMillan, 1967.

4) Harvey L. Dixon, Vance E. Miller, Jr., and Benjamin V. Andrews, "Overview of Transportation Trends, Cargo Forecasting, and Analytical Techniques”, Stanford Research Institute, 1969.

5) Litton Systems, Inc., “Oceanborne Shipping: Demand and Technology Forecast", Report to the U. S. Department of Transportation, 1968.

6) Harry Benford, Kent C. Thornton, and E.B. Williams, "Current Trends in the Design of Iron-Ore Ships", Transactions, SNAME Vol. 70, 1962, pp. 24 84.

7) Paulo S. Cotta, "Hull Cost as a Factor in Selecting Ship Speed", Department of Naval Architecture and Marine Engineering, The University of Michigan, 1970.

8) A. Silverleaf, "Ships of Tomorrow: Some Possibilities and Prospects", Transactions, North East Coast Institution, Vol.86, 1969 70, pp.73 78.

9) Wilhelm Prölss, "New Aspects in Ocean Shipping Economics: the Dynaship", unpublished document, 1970.

10) J. J. Servan-Schreiber, "The American Challenge", Atheneum, 2969.

11) F.H. Todd, interview in "Shipbuilding International", March 1968.

12) John Kenneth Galbraith, "The New Industrial State”, New American Library, 1968.

\section{Photo Credits}

Fig. 1. Univ. of Mich., College of Engineering

2. Caltex

3. Sea-Land Services, Inc.

4 .

5. Bell Aerosystems Co.

6. General Dynamics

7. Boeing Co.
Fig. 8. Same as 1

$9 . \quad$ "

10. Freide and Goldman

11. Marine Engineering/Log

12. Same as 1

13. " 